\title{
Effects of dietary Corynebacterium ammoniagenes-derived single cell protein on growth performance, blood and tibia bone characteristics, and meat quality of broiler chickens
}

\author{
B.-K. An ${ }^{1,4}$, Y.-I. Choi ${ }^{2,4}$, C.-W. Kang ${ }^{2}$ and K.-W. Lee ${ }^{1,3}$ \\ ${ }^{1}$ Konkuk University, Sanghuh College of Life Sciences, Department of Animal Science and Technology, \\ Seoul 05029, South Korea \\ ${ }^{2}$ SOLTON Biochem Inc, Seoul 06691, South Korea
}

KEY WORDS: single cell protein, growth performance, meat quality, bone characteristics, broilers

Received: 19 March 2017

Revised: 29 April 2018

Accepted: 8 June 2018

${ }^{3}$ Corresponding author: e-mail: kyungwoolee@konkuk.ac.kr ${ }^{4}$ Equal contribution

\begin{abstract}
In total six hundred, day-old Ross 308 male broiler chickens were fed one of four diets containing $0,10,30$ or $50 \mathrm{~g}$ of Corynebacterium ammoniagenes-derived single cell protein (SCP) per kg for 35 days to investigate the effect of graded level of SCP on growth performance, organ weights, serum and tibia characteristics, and meat quality. In each treatment were 5 replicates, 30 chickens per replicate. Graded levels of dietary SCP did not affect $(P>0.05$; linear or quadratic) daily weight gain of broilers at all ages. However, chickens fed a diet containing $10 \mathrm{~g} \mathrm{SCP} \cdot \mathrm{kg}^{-1}$ had higher $(P<0.05)$ body weight gain in comparison with the control group at days $1-21$. Dietary SCP linearly lowered $(P<0.05)$ feed intake at all ages, but quadratically enhanced feed conversion ratio at days 1-21 as the SCP levels in diets increased. Chickens fed the diet containing $10 \mathrm{~g} \mathrm{SCP} \cdot \mathrm{kg}^{-1}$ consumed more $(P<0.05)$ at days 22-35 and 1-35 as compared with the control group. Dietary SCP did not affect $(P>0.05)$ the relative weights of various organs, serum and tibia characteristics, and meat quality parameters. In conclusion, the obtained results suggest that C. ammoniagenes-derived SCP can be added at the level of $1 \%$ to broiler diet as a non-conventional protein source without any negative effects on blood and bone characteristics, and meat quality.
\end{abstract}

\section{Introduction}

Single cell protein (SCP) typically refers to sources of mixed protein extracted from pure and mixed cultures of microorganisms like yeasts, bacteria, fungi and algae, grown in large scale culture systems (Nasseri et al., 2011). SCP can be produced using a variety of raw substrates from inexpensive agro-industrial by-products and can be used in poultry feed as an alternative protein source to soyabean meal or fishmeal (El-Deek et al., 2009). Corynebacterium ammoniagenes, a small, non-moving Gram- positive soil bacterium, has been used on sugars as a substrate to produce amino acid such as L-lysine and inosine 5'-monophosphate. C. ammoniagenesderived SCP has been marketed in livestock industry as a functional feed supplement to promote growth or immune system development, or as a flavour enhancer to increase palatability. It contains crude protein $\left(609 \mathrm{~g} \mathrm{CP} \cdot \mathrm{kg}^{-1}\right.$ dry matter (DM)), ether extract $\left(79 \mathrm{~g} \mathrm{EE} \cdot \mathrm{kg}^{-1} \mathrm{DM}\right)$ and balanced amino acids. In comparison with fishmeal it is characterized by lower lysine content (Zhang et al., 2013). Zhang et al. (2013) further reported that C. ammoniagenes- 
derived SCP can effectively replace $50 \%$ of fishmeal without adverse effects on growth performance and nutrient digestibility in weaned pigs. However, the dietary effect of $C$. ammoniagenes-derived SCP in broiler chickens has not been evaluated. So, the aim of present study was to determine the effect of the graded levels of $C$. ammoniagenes-derived SCP on growth performance, blood and tibia characteristics, and meat quality in broiler chickens.

\section{Material and methods}

All animal procedures were approved by Institutional Animal Care (KU15186) and Use Committee in KonKuk University (South Korea).

\section{Nitrogen-corrected true metabolizable energy (TMEn) and digestible amino acids of SCP}

Initially, C. ammoniagenes-derived SCP were assayed for nitrogen-corrected true metabolizable energy (TMEn) and total and digestible amino acid contents. TMEn were measured using the precisionfed rooster assay as described by Sibbald (1979) and true amino acid availability (TAAA) by Likuski and Dorrell (1978). In brief, 12 Single Comb White Leghorn (SCWL) male roosters were housed in individual metabolic cages $(45 \times 62 \times 66 \mathrm{~cm})$. After $24 \mathrm{~h}$ of feed deprivation, $30 \mathrm{~g}$ of the ingredient were fed by crop intubation to 6 SCWL roosters. Another $6 \mathrm{SCWL}$ roosters were fasted for $48 \mathrm{~h}$ following the initial $24 \mathrm{~h}$ fasting period to estimate endogenous losses. Total excreta voided over the following 48-h period were frozen at $-20{ }^{\circ} \mathrm{C}$, dried to a constant weight at $65^{\circ} \mathrm{C}$, and ground for subsequent analyses.

TMEn value was calculated as follows:

$$
\begin{gathered}
\text { TMEn }\left(\mathrm{kcal} \cdot \mathrm{kg}^{-1}\right)=\left[\mathrm{GE}_{\mathrm{i}}-\left\{\mathrm{EE}_{\mathrm{f}}+\left(\mathrm{N}_{\mathrm{i}}-\mathrm{N}_{\mathrm{e}}\right) \times\right.\right. \\
\left.\quad \times 8.73\}-\left\{\mathrm{EE}_{\mathrm{e}}+\left(\mathrm{N}_{\mathrm{i}}-\mathrm{N}_{\mathrm{e}}\right) \times 8.73\right\}\right] / \mathrm{X}
\end{gathered}
$$

where: $\mathrm{GE}_{\mathrm{f}}$ - gross energy ingested; $\mathrm{EE}_{\mathrm{f}}$ - energy excreted fed roosters; $\mathrm{EE}_{\mathrm{e}}$ - energy excreted by fasted roosters; $\mathrm{N}_{\mathrm{i}}$ - nitrogen ingested; $\mathrm{N}_{\mathrm{e}}$ - nitrogen excreted; and $\mathrm{X}$ - weight of the ingredient $(\mathrm{kg})$.

TAAA value was calculated for each amino acid using the following equation:

$$
\mathrm{TAAA}=\left[\mathrm{AA}_{\mathrm{c}}-\left(\mathrm{AA}_{\mathrm{v}}-\mathrm{AA}_{\mathrm{vf}}\right)\right] / \mathrm{AA}_{\mathrm{c}} \times 100
$$

where: $\mathrm{AA}_{\mathrm{c}}$ - total amount of amino acid consumed by the rooster; $\mathrm{AA}_{\mathrm{v}}$ - total amount of amino acid voided in excreta by the fed rooster; and $\mathrm{AA}_{\mathrm{vf}}-$ amount of each amino acid voided by the fasted rooster. For correction to zero nitrogen, a value of $8.73 \mathrm{kcal} \cdot \mathrm{g}^{-1}$ of nitrogen retained was used (Sibbald,
1982). Samples of the diet and excreta were assayed for gross energy using bomb calorimeter (C2000 bomb calorimeter, IKA ${ }^{\circledR}$, Staufen, Germany) and for amino acids using HPLC (L-6200 system, Hitachi Co., Ltd., Tokyo, Japan).

It was found that $C$. ammoniagenes-derived SCP contained $60.94 \%$ crude protein and $13.54 \mathrm{MJ}$ TMEn $\cdot \mathrm{kg}^{-1}$ SCP. Analysed total and digestible amino acid contents ( $\mathrm{g} \cdot 100 \mathrm{~g}^{-1} \mathrm{SCP}, \mathrm{DM}$ basis) in C. ammoniagenes-derived SCP were as follows: threonine $(2.93,2.45)$, valine $(2.86,2.38)$, methionine $(2.78,2.61)$, isoleucine $(2.27,1.95)$, leucine (4.66, 3.89), phenylalanine $(2.61,2.13)$, lysine $(1.91,1.63)$, histidine $(1.10,0.98)$, arginine $(2.42$, $2.13)$ and proline $(2.04,1.10)$, respectively. Analysed nutrient composition of SCP is provided in Table 1.

Table 1. Analyzed chemical composition and nitrogen-corrected true metabolizable energy (TMEn) of single cell protein

\begin{tabular}{lr}
\hline Indices & Single cell protein \\
\hline Chemical composition, $\%$ & \\
dry matter (DM) & 96.02 \\
crude protein & 60.94 \\
crude fat & 7.94 \\
crude ash & 7.15 \\
crude fiber & 1.40 \\
starch & 0.18 \\
TMEn, MJ $\cdot \mathrm{kg}^{-1}$ DM basis & 13.54 \\
Amino acid, \% DM basis & \\
aspartic acid & 6.41 \\
threonine & 2.93 \\
serine & 2.58 \\
glutamic acid & 7.91 \\
alanine & 6.99 \\
valine & 2.86 \\
methionine & 2.78 \\
isoleucine & 2.27 \\
leucine & 4.66 \\
tyrosine & 1.26 \\
phenylalanine & 2.61 \\
lysine & 1.91 \\
histidine & 1.10 \\
arginine & 2.42 \\
proline & 2.04 \\
\hline
\end{tabular}

\section{Animals, diets and experimental design}

In total, six hundred day-old male (ROSS 308) chickens were purchased from a local hatchery, individually weighed, randomly assigned into 20 floor pens with rice husk as a bedding material, and subjected to one of four dietary treatments ( 30 chickens per replicate, 5 replicates per treatment). Control diet consisted of maize and soyabean meal in a mash form. The experimental diets were formulated by 
adding $C$. ammoniagenes-derived SCP to the control diet to reach 10, 30, and $50 \mathrm{~g}$ per $\mathrm{kg}$ of diet. All four diets in mashed form were formulated to be equal in the contents of TMEn, and digestible lysine and total sulphur amino acids (Table 2). The starter diet was fed at 1-21 days of age and the finisher at 22-35 days of age. All diets were free from coccidiostats. C. ammoniagenes-derived SCP (Protide ${ }^{\circledR}$, Cheiljedang Co. Ltd, Seoul, South Korea) used in this study is commercially available protein supplement or flavour enhancer in animal industry. All experimental diets were formulated to meet or exceed nutrient requirements of National Research Council (NRC, 1994). The diets and water were provided ad libitum. Chickens were initially reared at $33{ }^{\circ} \mathrm{C}$ and the room temperature was gradually reduced by $4{ }^{\circ} \mathrm{C}$ weekly until a final temperature of $23{ }^{\circ} \mathrm{C}$ was reached. A $23 / 1$ light/dark cycle was used throughout the 35-day experiment.

\section{Sampling}

Body weight and feed intake on a pen basis were recorded weekly and feed conversion ratio per pen was also calculated. At the end of the experimental period, one non-fasted bird per replicate was random- ly selected, weighed and euthanized with carbon dioxide. Immediately after euthanasia, blood was taken via cardiac puncture. Sera were obtained by gentle centrifugation and stored at $-20{ }^{\circ} \mathrm{C}$ prior to further use. Immediately after blood sampling, internal organs including liver, bursa of Fabricius, abdominal fat, and the right breast (pectoralis major and pectoralis minor) and leg (biceps femoris) were immediately removed and weighed. Then, the right breast and leg were frozen at $-20{ }^{\circ} \mathrm{C}$ until subsequent determination of meat quality and tibia characteristics.

\section{Serum analysis}

The concentrations of serum total cholesterol, total albumin and blood urea nitrogen (BUN), and the activities of glutamic-oxaloacetic transaminase (GOT) and glutamic-pyruvic transaminase (GPT) were measured colorimetrically as described by Lee et al. (2016).

\section{Measurement of tibia characteristics}

Right drumsticks were deboned and bone breaking strength of the tibia was measured using an Instron (Model 3342, Instron Universal Testing

Table 2. Formula and chemical compositions of the experimental diets, $\mathrm{g} \cdot \mathrm{kg}^{-1}$ of diet, as fed (unless otherwise stated)

\begin{tabular}{|c|c|c|c|c|c|c|c|c|}
\hline \multirow{2}{*}{ Indices } & \multicolumn{4}{|l|}{ Starter $^{1}$} & \multicolumn{4}{|c|}{ Finisher $^{1}$} \\
\hline & SCPO & SCP1 & SCP3 & SCP5 & SCPO & SCP1 & SCP3 & SCP5 \\
\hline \multicolumn{9}{|l|}{ Ingredients } \\
\hline yellow maize & 578.4 & 584.1 & 595.3 & 606.7 & 641.9 & 647.7 & 658.8 & 660.8 \\
\hline soyabean meal & 303.2 & 290.4 & 264.9 & 239.3 & 254.2 & 241.4 & 215.7 & 205.0 \\
\hline maize gluten meal & 50.0 & 50.0 & 50.0 & 50.0 & 40.0 & 40.0 & 40.0 & 30.4 \\
\hline tallow & 29.0 & 25.9 & 19.8 & 13.6 & 25.8 & 22.7 & 16.6 & 15.0 \\
\hline single cell protein & 0.0 & 10.0 & 30.0 & 50.0 & 0.0 & 10.0 & 30.0 & 50.0 \\
\hline dicalcium phosphate & 20.2 & 20.0 & 19.5 & 19.1 & 14.9 & 14.7 & 14.3 & 13.8 \\
\hline L-lysine $\cdot \mathrm{HCl}(78 \%)$ & 0.4 & 0.6 & 0.9 & 1.3 & 0.8 & 1.0 & 1.4 & 1.5 \\
\hline DL-methionine (98\%) & 1.2 & 1.1 & 1.0 & 0.9 & 0.9 & 0.8 & 0.8 & 0.8 \\
\hline limestone & 11.6 & 11.8 & 12.3 & 12.7 & 15.2 & 15.4 & 15.9 & 16.2 \\
\hline choline-Cl (50\%) & 0.5 & 0.6 & 0.8 & 0.9 & 0.8 & 0.8 & 1.0 & 1.0 \\
\hline salt & 3.0 & 3.0 & 3.0 & 3.0 & 3.0 & 3.0 & 3.0 & 3.0 \\
\hline vitamin-mineral mixture ${ }^{2}$ & 2.5 & 2.5 & 2.5 & 2.5 & 2.5 & 2.5 & 2.5 & 2.5 \\
\hline \multicolumn{9}{|c|}{ Calculated nutrient composition } \\
\hline $\mathrm{TMEn}^{3}, \mathrm{MJ} \cdot \mathrm{kg}^{-1}$ & 12.89 & 12.89 & 12.89 & 12.89 & 13.10 & 13.10 & 13.10 & 13.10 \\
\hline crude protein & 215 & 215 & 215 & 215 & 190 & 190 & 190 & 190 \\
\hline $\mathrm{Ca}$ & 10 & 10 & 10 & 10 & 10 & 10 & 10 & 10 \\
\hline available P & 4.5 & 4.5 & 4.5 & 4.5 & 3.5 & 3.5 & 3.5 & 3.5 \\
\hline digestible Lys & 9.5 & 9.5 & 9.5 & 9.5 & 8.6 & 8.6 & 8.6 & 8.6 \\
\hline digestible TSAA ${ }^{4}$ & 7.6 & 7.6 & 7.6 & 7.6 & 6.9 & 6.9 & 6.9 & 6.9 \\
\hline digestible Met & 4.6 & 4.6 & 4.6 & 4.6 & 4.2 & 4.2 & 4.2 & 4.2 \\
\hline
\end{tabular}

${ }^{1}$ treatments: SCPO - no single cell protein added, SCP1 - single cell protein at $10 \mathrm{~g} \cdot \mathrm{kg}^{-1}$ of diet, SCP3 - single cell protein at $30 \mathrm{~g} \cdot \mathrm{kg}^{-1}$ of diet, SCP5 - single cell protein at $50 \mathrm{~g} \cdot \mathrm{kg}^{-1}$ of diet; ${ }^{2}$ vitamin-mineral premix provided the following nutrients per $\mathrm{kg}$ of diet: IU: vit. A 14000 , vit. $D_{3} 3000$, vit. $E 40$; mg: vit. $K_{3} 2.4$, vit. $B_{1} 1.2$, vit $B_{2} 5$, vit. $B_{6} 3$, vit. $B_{12} 0.02$, biotin 0.07 , pantothenic acid 10 , folic acid 0.5 , nicotinic acid 40 , Fe 32, Zn 40, Mn 48, Co 0.16, Cu 3.33, Se 0.12, I 0.67; ${ }^{3}$ TMEn - nitrogen-corrected true metabolizable energy; ${ }^{4} \mathrm{TSAA}$ - total sulphur amino acid 
Machine, Instron Corp., Norwood, MA, USA) as described by $\mathrm{Oh}$ et al. (2015). The sheared tibia pieces were collected and de-fatted, after which the tibia samples were oven-dried at $105{ }^{\circ} \mathrm{C}$ for $24 \mathrm{~h}$ and then weighed to obtain the fat-free dry weight. The tibia samples were placed in a muffle furnace (Isotemp muffle furnace, Fisher Scientific, Hampton, NW, USA) at $600{ }^{\circ} \mathrm{C}$ for $2 \mathrm{~h}$, and manually ground in a mortar before mineral content determination. Measurements of $\mathrm{Ca}$ and $\mathrm{P}$ were performed with an inductively coupled plasma emission spectroscopy (ICP) (Opima 2100 DV, Perkin Elmer, Waltham, MA, USA).

\section{Measurement of meat quality}

The breast meat samples were weighed to determine cooking loss, water holding capacity (WHC), $\mathrm{pH}$ and meat colour at $24 \mathrm{~h}$ post-mortem. To determine the cooking loss, $60 \mathrm{~g}$ of breast meat was boiled individually in a polyethylene bag immersed in $80{ }^{\circ} \mathrm{C}$ water bath for $30 \mathrm{~min}$ and cooled at room temperature for $30 \mathrm{~min}$. The cooking loss was calculated from difference in the weights of uncooked and cooked meats. The WHC was estimated by filter paper pressed method (Grau and Hamm, 1953). A sample of $300 \mathrm{mg}$ of breast meat was weighed on a Whatman filter paper (No. 2, Whatman International Ltd., Maidstone, UK). The samples were pressed between two plexiglass plates for $3 \mathrm{~min}$ at $1 \mathrm{~kg}$ load. The areas of pressed sample and water were measured using planimeter (Type KP-21, Mitutoyo, Kawasaki-shi, Japan). The $\mathrm{pH}$ values of breast meats were estimated in triplicate. Briefly, the meat $(1 \mathrm{~g})$ was homogenized with $9 \mathrm{ml}$ of distilled water for 1 min using an Ultra-Turrax (Model No. T25, Janken \& Kunkel, Staufen, Germany) and the homogenate was used to measure $\mathrm{pH}$ (Model 340, Mettler-Toledo, Greifensee, Switzerland). The instrumental colour of fresh meat was measured by a Chromameter (CR 210, Minolta, Tokyo, Japan). Colour for each sample was expressed in terms of Commission International de l'Eclairage values for lightness $\left(\mathrm{L}^{*}\right)$, redness $\left(\mathrm{a}^{*}\right)$ and yellowness $\left(\mathrm{b}^{*}\right)$, and was obtained using the average value of three measurements taken from the bone-side surface of each sample. The colorimeter was calibrated throughout the study using a standard white ceramic tile.

\section{Statistical analysis}

All data (i.e. production traits, relative weights of organs and tissues, and blood, tibia and meat quality characteristics) obtained in this study were analysed using the general linear model procedure (PROC GLM) of SAS version 9.2 (SAS Institute Inc., Cary, NC, USA). Duncan's multiple range test was used to compare the means of the treatments (Duncan, 1955). Additionally, orthogonal polynomial contrast was used to determine the linear and quadratic effects of dietary SCP. Criterion for statistical significant was pre-set at $P<0.05$.

\section{Results}

Daily weight gain was not affected $(P>0.05$, linear and quadratic) by graded levels of $C$. ammoniagenes-derived SCP at any phases of production (Table 3). However, chickens fed diet containing $10 \mathrm{~g} \mathrm{SCP} \cdot \mathrm{kg}^{-1}$ grew faster $(P<0.05)$ in comparison with the chickens fed control diet (1-21 days). At 1-21 days, the quadratic effect of C. ammoniagenes-derived SCP on feed conversion ratio was noted. During this phase, chickens fed the diet

Table 3. The dietary effect of Corynebacterium ammoniagenes-derived single cell protein (SCP) supplementation on growth performance in broiler chicks

\begin{tabular}{|c|c|c|c|c|c|c|c|}
\hline \multirow{2}{*}{ Indices } & \multicolumn{4}{|c|}{ Treatment $^{1}$} & \multirow{2}{*}{ SEM } & \multicolumn{2}{|c|}{ Polynomial contrasts } \\
\hline & SCPO & SCP1 & SCP3 & SCP5 & & $P$ linear & $P$ quadratic \\
\hline \multicolumn{8}{|c|}{ Body weight gain, $\mathrm{g} \cdot$ day $^{-1} \cdot$ bird $^{-1}$} \\
\hline days $1-21$ & $32.7^{b}$ & $34.9^{\mathrm{a}}$ & $33.2^{b}$ & $33.0^{b}$ & 0.42 & 0.330 & 0.089 \\
\hline $22-35$ & 71.7 & 73.1 & 69.9 & 67.8 & 2.28 & 0.138 & 0.668 \\
\hline $1-35$ & 48.8 & 50.6 & 48.3 & 47.3 & 0.95 & 0.091 & 0.378 \\
\hline \multicolumn{8}{|c|}{ Feed intake, $g \cdot$ day $^{-1} \cdot$ bird $^{-1}$} \\
\hline days $1-21$ & $50.1^{\mathrm{a}}$ & $50.2^{\mathrm{a}}$ & $48.8^{\mathrm{b}}$ & $48.8^{b}$ & 0.31 & 0.001 & 0.481 \\
\hline $22-35$ & $155.3^{b}$ & $159.8^{\mathrm{a}}$ & $154.7^{\mathrm{b}}$ & $153.8^{b}$ & 0.17 & 0.040 & 0.198 \\
\hline $1-35$ & $93.4^{b}$ & $95.1^{\mathrm{a}}$ & $92.3^{b}$ & $92.0^{\mathrm{b}}$ & 0.50 & 0.003 & 0.478 \\
\hline \multicolumn{8}{|c|}{ Feed conversion ratio, $\mathrm{g} \cdot \mathrm{g}^{-1}$} \\
\hline days $1-21$ & $1.53^{\mathrm{a}}$ & $1.44^{b}$ & $1.47^{\mathrm{ab}}$ & $1.48^{\mathrm{ab}}$ & 0.02 & 0.324 & 0.047 \\
\hline $22-35$ & 2.18 & 2.19 & 2.23 & 2.27 & 0.06 & 0.304 & 0.951 \\
\hline $1-35$ & 1.92 & 1.88 & 1.92 & 1.95 & 0.03 & 0.366 & 0.467 \\
\hline
\end{tabular}

${ }^{1}$ see Table 2; ab - means with different superscripts within a row are significantly different at $P<0.05$ according to Duncan's multiple range test 
Table 4. Dietary effect of Corynebacterium ammoniagenes-derived single cell protein (SCP) on relative weights of various organs and tissues in broiler chickens

\begin{tabular}{|c|c|c|c|c|c|c|c|}
\hline \multirow{2}{*}{$\begin{array}{l}\text { Body parts, } \mathrm{g} \cdot 100 \mathrm{~g}^{-1} \text { of live } \\
\text { body weight }\end{array}$} & \multicolumn{4}{|c|}{ Treatment $^{1}$} & \multirow{2}{*}{ SEM } & \multicolumn{2}{|c|}{ Polynomial contrasts } \\
\hline & SCPO & SCP1 & SCP3 & SCP5 & & $P$ linear & $P$ quadratic \\
\hline Liver & 2.26 & 1.95 & 2.06 & 2.02 & 0.11 & 0.322 & 0.302 \\
\hline Spleen & 0.11 & 0.09 & 0.13 & 0.12 & 0.01 & 0.215 & 0.967 \\
\hline Bursa of Fabricius & 0.18 & 0.21 & 0.22 & 0.22 & 0.02 & 0.099 & 0.258 \\
\hline Abdominal fat & 1.92 & 1.76 & 1.66 & 1.74 & 0.09 & 0.199 & 0.157 \\
\hline Right breast muscle & 7.44 & 7.48 & 7.61 & 7.43 & 0.18 & 0.923 & 0.492 \\
\hline Right leg & 9.83 & 9.55 & 9.77 & 9.75 & 0.17 & 0.905 & 0.609 \\
\hline
\end{tabular}

${ }^{1}$ see Table 2

Table 5. Dietary effect of Corynebacterium ammoniagenes-derived single cell protein (SCP) on blood parameters and tibia characteristics in broiler chickens

\begin{tabular}{|c|c|c|c|c|c|c|c|}
\hline \multirow{2}{*}{ Indices $^{1}$} & \multicolumn{4}{|c|}{ Treatment $^{2}$} & \multirow{2}{*}{ SEM } & \multicolumn{2}{|c|}{ Polynomial contrasts } \\
\hline & SCPO & SCP1 & SCP3 & SCP5 & & $P$ linear & $P$ quadratic \\
\hline \multicolumn{8}{|l|}{ Blood profile } \\
\hline $\mathrm{GOT}, \mathrm{IU} \cdot \mathrm{I}^{-1}$ & 99.78 & 99.16 & 97.83 & 96.33 & 2.39 & 0.287 & 0.967 \\
\hline $\mathrm{GPT}, \mathrm{U} \cdot \mathrm{I}^{-1}$ & 9.05 & 10.73 & 9.40 & 9.10 & 0.84 & 0.603 & 0.419 \\
\hline T-Cho, $\mathrm{mg} \cdot \mathrm{dl}^{-1}$ & 134.7 & 129.3 & 114.2 & 127.7 & 6.03 & 0.248 & 0.060 \\
\hline albumin, $\mathrm{g} \cdot \mathrm{dl}^{-1}$ & 1.21 & 1.08 & 1.23 & 1.25 & 0.04 & 0.110 & 0.278 \\
\hline BUN, mg $\cdot \mathrm{dl}^{-1}$ & 3.11 & 3.01 & 2.94 & 2.96 & 0.15 & 0.486 & 0.620 \\
\hline \multicolumn{8}{|l|}{ Tibia characteristics } \\
\hline length, cm & 9.50 & 9.53 & 9.53 & 9.43 & 0.06 & 0.381 & 0.326 \\
\hline weight, $\mathrm{g} \cdot 100 \mathrm{~g}^{-1}$ of BW & 0.70 & 0.71 & 0.75 & 0.71 & 0.01 & 0.358 & 0.110 \\
\hline breaking strength, KN & 0.28 & 0.28 & 0.29 & 0.30 & 0.02 & 0.248 & 0.876 \\
\hline $\begin{array}{l}\text { ash, } g \cdot 100 \mathrm{~g}^{-1} \text { of fat-free } \\
\text { tibia }\end{array}$ & 47.98 & 49.27 & 46.01 & 48.74 & 0.90 & 0.774 & 0.149 \\
\hline Calcium, $\%$ of ash & 36.11 & 36.35 & 35.70 & 35.51 & 0.40 & 0.173 & 0.871 \\
\hline Phosphorus, $\%$ of ash & 17.60 & 17.63 & 17.85 & 17.44 & 0.19 & 0.682 & 0.183 \\
\hline
\end{tabular}

${ }_{1}$ GOT - glutamic-oxaloacetic transaminase, GPT - glutamic-pyruvic transaminase, T-Cho - total cholesterol, BUN - blood urea nitrogen, BW - body weight; ${ }^{2}$ see Table 2

Table 6. Dietary effect of Corynebacterium ammoniagenes-derived single cell protein (SCP) on broiler chickens meat qualities

\begin{tabular}{|c|c|c|c|c|c|c|c|}
\hline \multirow{2}{*}{ Indices } & \multicolumn{4}{|c|}{ Treatment $^{1}$} & \multirow{2}{*}{ SEM } & \multicolumn{2}{|c|}{ Polynomial contrasts } \\
\hline & SCPO & SCP1 & SCP3 & SCP5 & & $P$ linear & $P$ quadratic \\
\hline Cooking loss, $\%$ & 19.36 & 21.04 & 21.13 & 21.74 & 1.18 & 0.244 & 0.630 \\
\hline Shear force, kgf & 2.58 & 2.50 & 2.38 & 2.37 & 0.16 & 0.352 & 0.714 \\
\hline \multicolumn{8}{|l|}{$\mathrm{pH}$} \\
\hline breast muscle & 5.69 & 5.75 & 5.76 & 5.75 & 0.02 & 0.185 & 0.147 \\
\hline leg muscle & 6.32 & 6.34 & 6.48 & 6.25 & 0.09 & 0.761 & 0.108 \\
\hline \multicolumn{8}{|c|}{ Breast muscle colour ${ }^{2}$} \\
\hline$L^{*}$ & 58.20 & 56.58 & 56.33 & 59.23 & 1.28 & 0.495 & 0.110 \\
\hline$a^{*}$ & 0.78 & 1.46 & 0.68 & 0.88 & 0.25 & 0.487 & 0.740 \\
\hline$b^{*}$ & 9.49 & 7.93 & 8.99 & 6.92 & 0.94 & 0.161 & 0.669 \\
\hline \multicolumn{8}{|l|}{ Leg colour ${ }^{2}$} \\
\hline$L^{*}$ & 55.81 & 57.45 & 51.85 & 55.74 & 2.00 & 0.508 & 0.293 \\
\hline$a^{*}$ & 4.61 & 2.88 & 3.49 & 4.08 & 0.82 & 0.961 & 0.246 \\
\hline$b^{*}$ & 7.85 & 8.27 & 7.78 & 6.51 & 0.65 & 0.109 & 0.307 \\
\hline
\end{tabular}

${ }^{1}$ see Table $2 ;{ }^{2} L^{*}-$ lightness, $a^{*}-$ redness, $b^{*}$ - yellowness 
containing $10 \mathrm{~g} \mathrm{SCP} \cdot \mathrm{kg}^{-1}$ had lower $(P<0.05)$ feed conversion ratio as compared with that of control group. Feed intake linearly decreased $(P<0.05)$ with increasing levels of $C$. ammoniagenes-derived $\mathrm{SCP}$ at all ages although chickens fed diets containing $10 \mathrm{~g} \mathrm{SCP} \cdot \mathrm{kg}^{-1}$ consumed more $(P<0.05)$ than the control group during the finisher or whole periods. Other than the production traits measured, the graded levels of $C$. ammoniagenes-derived SCP in the diets of broiler chickens did not affect $(P>0.05$; linear or quadratic) relative weights of organs or tissues (Table 4), and blood profiles (i.e. GOT and GPT activities, and total cholesterol, albumin and BUN contents) (Table 5). In addition, none of tibia parameters (length, weight, breaking strength, and ash, calcium and phosphorus contents) was affected by dietary SCP (Table 5). Finally, dietary SCP failed to affect meat characteristics (i.e. cooking loss, shear force, $\mathrm{pH}$, meat colour) (Table 6).

\section{Discussion}

Chickens at the end of the experiment weighed on average $1.7 \mathrm{~kg}$. According to the performance objectives for ROSS 308 (Aviagen, 2014a), the body weight at 35 day should be around $2.2 \mathrm{~kg}$. This huge difference in live body weight at 35 day might be due to the current experiment design which used low nutrient density (digestible lysine $9.5 \mathrm{~g} \cdot \mathrm{kg}^{-1}$ of diet for the starter) and a 2-phase feeding programme (starter and finisher) rather than high nutrient density (digestible lysine $12.8 \mathrm{~g} \cdot \mathrm{kg}^{-1}$ of diet for the starter period) and a 3-phase feeding programme (starter, grower and finisher) recommended by ROSS 308 nutrition specifications (Aviagen, 2014b). It is well reported that chicken performed better in response to lysine levels in equal crude protein contents (Sterling et al., 2003). All chickens were healthy, and no signs of feed refusal were observed.

It was clearly shown that $C$. ammoniagenesderived SCP, when added above $30 \mathrm{~g} \cdot \mathrm{kg}^{-1}$ to broiler diet, impaired feed intake, but it did not affect weight gain and feed conversion ratio. The reasons for the decreased feed intake, especially at higher incorporation level of SCP, may be associated with free adenine or unknown components present in bacteria-derived SCP in chickens (Øverland et al., 2010). It was reported that the current SCP product contained $31.4 \mathrm{~g}$ total nucleotides $\cdot \mathrm{kg}^{-1}$ and $7.8 \mathrm{~g}$ guanine $\cdot \mathrm{kg}^{-1}$ (Wang et al., 2013). Thus, the nucleotide content present in SCP may be the readily available explanation in lowered feed intake. Alternatively, dietary chloride contents increased by on average $0.14 \%$ unit between control diet and diet with SCP at the level of $50 \mathrm{~g} \cdot \mathrm{kg}^{-1}$ due to difference in lysine- $\mathrm{HCl}$ levels and feed ingredients used. Thus, unbalanced chloride contents between dietary treatments may in part contribute to the observed depression in feed intake although this difference did not affect feed intake in broiler chickens (Murakami et al., 1997). Nonetheless, our study is considered to be promising as dietary SCP, when added at $1 \%$ to the diet, enhanced weight gain and feed conversion ratio at early phase. This result is in contrast to previous reports showing that dietary bacteria-derived cell protein linearly reduced both feed intake, weight gain (Waldroup and Payne, 1974), and feed efficiency (Chiou et al., 2001). Interestingly, in chickens fed dietary $C$. ammoniagenes-derived SCP at the level of $10 \mathrm{~g} \cdot \mathrm{kg}^{-1}$ feed intake was stimulated, weight gain was increased, and feed conversion ratio was enhanced in comparison with the control animals. Thus, it seems that incorporation of SCP at $1 \%$ into the diet of chickens could be of practical relevance, which may increase feed utilization efficiency.

Graded supplementation of $C$. ammoniagenesderived SCP did not affect blood parameters such as total cholesterol, albumin and BUN contents, and GOT and GPT activities. All serum parameters except for GPT and GOP activities were within the reference ranges for chickens. For example, Bowes et al. (1989) reported the biochemical values of cholesterol (115.2-163.6 mg $\left.\cdot \mathrm{dl}^{-1}\right)$, albumin (1.18$\left.1.37 \mathrm{mg} \cdot \mathrm{dl}^{-1}\right)$ and GOT $\left(184-273 \mathrm{IU} \cdot 1^{-1}\right)$ in broiler chickens. In addition, mean BUN concentration is reported to be $3.11 \mathrm{mg} \cdot \mathrm{dl}^{-1}$ in avian plasma (Scanes, 2015). It is not clear why the values for GOT activity obtained in this study are far lower than those published elsewhere (Bowes et al., 1989). However, Adil et al. (2010) observed serum GOT $\left(95.6-100.5 \mathrm{IU} \cdot \mathrm{dl}^{-1}\right)$ and GPT $\left(15.0-17.6 \mathrm{IU} \cdot \mathrm{dl}^{-1}\right)$ levels in broiler chickens that were similar to those obtained in the current study. Serum GOT and GPT are considered as the indicators of normal liver functions and are often used to determine a safe inclusion level for non-conventional feedstuffs (Diaz et al., 2003). It has been known that both GOT and GPT increase with increasing Aspergillus nigerderived SCP in the diets of broiler chickens (Chiou et al., 2001), which was not the case in this study. Previously, hypocholesterolaemic effect by dietary SCP was seen in adult mink, which was attributed to the presence of phospholipid components in SCP (Øverland et al., 2010). In this study, the non-significant, quadratic effect $(P=0.060)$ by dietary SCP on serum cholesterol was detected. 
However, our finding should be interpreted with caution as tallow as a fat source was gradually reduced as dietary SCP increased. Thus, the observed hypocholesterolaemic effect by dietary SCP (Øverland et al., 2010) cannot be explained in this study.

In addition to serum characteristics, tibia characteristics (i.e. length, breaking strength, and ash, $\mathrm{Ca}$ and $\mathrm{P}$ contents) and relative organ weights (i.e. liver, spleen, bursa of Fabricius and abdominal fat) were not affected by graded levels of $C$. ammoniagenesderived SCP. Thus, it is likely that dietary C. ammoniagenes-derived SCP used in this study did not exhibit any negative effects on liver function and bone metabolism in broiler chickens. Finally, dietary C. ammoniagenes-derived SCP did not affect meat yields and meat quality, of which result corroborates with previous study with $A$. niger-derived SCP in broiler chickens (Chiou et al., 2001).

\section{Conclusions}

The graded level of Corynebacterium ammoniagenes-derived single cell protein (SCP) failed to affect growth performance and characteristics of blood, tibia and meats in broiler chickens. However, as in chickens fed a diet containing $10 \mathrm{~g} \mathrm{SCP} \cdot \mathrm{kg}^{-1}$ of diet the performance was better than in the control group, maximum dietary inclusion level of C. ammoniagenes-derived SCP should be equal to or less than $1 \%$.

\section{Acknowledgements}

This work was supported by Korean Institute of Planning and Evaluation for Technology in Food, Agriculture, Forestry and Fishery (IPET) through Agri-Bio Industry Technology Development Program, funded by Ministry of Agriculture, Food and Rural Affairs (MAFRA)(316036-3).

\section{References}

Adil S., Banday T., Bhat G.A., Mir M.S., Rheman M., 2010. Effect of dietary supplementation of organic acids on performance, intestinal histomorphology, and serum biochemistry of broiler chicken. Vet. Med. Int. 2010, 479485, https://doi. org/10.4061/2010/479485

Aviagen, 2014a. Broiler performance objectives. http://eu.aviagen. com/assets/Tech_Center/Ross_Broiler/Ross-308-BroilerPO-2014-EN.pdf Accessed April 2, 2018

Aviagen, 2014b. Broiler nutrition specifications. http://eu.aviagen. com/assets/Tech_Center/Ross_Broiler/Ross-308-BroilerNutrition-Specs-2014r17-EN.pdf Accessed April 2, 2018
Bowes V.A., Julian R.J., Stirtzinger T., 1989. Comparison of serum biochemical profiles of male broilers with female broilers and White Leghorn chickens. Can. J. Vet. Res. 53, 7-11

Chiou P.W.S., Chiu S.W., Chen C.R., 2001. Value of Aspergillus niger fermentation product as a dietary ingredient for broiler chickens. Anim. Feed Sci. Technol. 91, 171-182, https://doi. org/10.1016/S0377-8401(01)00224-3

Diaz G.J., Roldán L.P., Cortés A., 2003. Intoxication of Crotalaria pallida seeds to growing broiler chicks. Vet. Hum. Toxicol. 45, 187-189

Duncan D.B., 1955. Multiple range and multiple F-test. Biometrics 11, 1-42, https://doi.org/10.2307/3001478

El-DeekA.A., Ghonem K.M., Hamdy S.M., Aser M.A., Aljassas F.M., Osman M.M., 2009. Producing single cell protein from poultry manure and evaluation for broiler chickens diets. Int. J. Poult. Sci. 8, 1062-1077, https://doi.org/10.3923/ijps.2009.1062.1077

Grau R., Hamm R.A., 1953. A simple method for the determination of water binding in muscles (in German). Naturwissenschaften 40, 29-30, https://doi.org/10.1007/BF00595734

Lee K.W., Lee K.C., Kim G.H., Kim J.H., Yeon J.S., Cho S.B., Chang B.J., Kim S.K., 2016. Effects of dietary fermented garlic on the growth performance, relative organ weights, intestinal morphology, cecal microflora and serum characteristics of broiler chickens. Rev. Bras. Cienc. Avic. 18, 511-518, http:// dx.doi.org/10.1590/1806-9061-2016-0242

Likuski H.J.A., Dorrell H.G., 1978. A bioassay for rapid determinations of amino acid availability values. Poult. Sci. 57, 1658-1660, https://doi.org/10.3382/ps.0571658

Murakami A.E., Watkins S.E., Saleh E.A., England J.A., Waldroup P.W., 1997. Estimation of the sodium and chloride requirements for the young broiler chick. J. Appl. Poult. Sci. 6, 155-162, https:// doi.org/10.1093/japr/6.2.155

Nasseri A.T., Rasoul-Amini S., Morowvat M.H., Ghasemi Y., 2011. Single cell protein: production and process. Am. J. Food Technol. 6, 103-116, https://doi.org/10.3923/ajtt.2011.103.116

National Research Council (NRC), 1994. Nutrient Requirements of Poultry: gth $^{\text {th }}$ Revised Edition. The National Academies Press. Washington, DC (USA), https://doi.org/10.17226/2114

Oh S.T., Zheng L., Kwon H.J., Choo Y.K., Lee K.W., Kang C.W., An B.K., 2015. Effects of dietary fermented Chlorella vulgaris $\left(\mathrm{CBT}^{\circledR}\right)$ on growth performance, relative organ weights, cecal microflora, tibia bone characteristics, and meat qualities in $\mathrm{Pe}$ kin ducks. Asian-Australas. J. Anim. Sci. 28, 95-101, https:// doi.org/10.5713/ajas.14.0473

Øverland M., Tauson A.-H., Shearer K., Skrede A., 2010. Evaluation of methane-utilising bacteria products as feed ingredients for monogastric animals. Arch. Anim. Nutr. 64, 171-189, https:// doi.org/10.1080/17450391003691534

Scanes C.G., 2015. Blood. In: C.G. Scanes (Editor). Sturkie's Avian Physiology. $6^{\text {th }}$ Edition. Academic Press (Elsevier). London (UK), pp. 167-191, https://doi.org/10.1016/B978-0-12-4071605.00010-5

Sibbald I.R., 1979. A bioassay for available amino acids and true metabolizable energy in feedingstuffs. Poult. Sci. 58, 668-673, https://doi.org/10.3382/ps.0580668

Sibbald I.R., 1982. Measurement of bioavailable energy in poultry feedingstuff: A review. Can. J. Anim. Sci. 62, 983-1048, https://doi. org/10.4141/cjas82-123

Sterling K.G., Pesti G.M., Bakalli R.I., 2003. Performance of broiler chicks fed various levels of dietary lysine and crude protein. Poult. Sci. 82, 1939-1974, https://doi.org/10.1093/ ps/82.12.1939 
Waldroup P.W., Payne J.R., 1974. The feeding value of methanolderived single cell protein for broiler chicks. Poult. Sci. 53, 1039-1042, https://doi.org/10.3382/ps.0531039

Wang J.P., Kim J.D., Kim J.E., Kim I.H., 2013. Amino acid digestibility of single cell protein from Corynebacterium ammoniagenes in growing pigs. Anim. Feed Sci. Technol. 180, 111-114, https:// doi.org/10.1016/j.anifeedsci.2012.12.006
Zhang H.Y., Piao X.S., Li P., Yi J.Q., Zhang Q., Li Q.Y., Liu J.D., Wang G.Q., 2013. Effects of single cell protein replacing fish meal in diet on growth performance, nutrient digestibility and intestinal morphology in weaned pigs. Asian-Australas. J. Anim. Sci. 26, 1320-1328, https://doi.org/10.5713/ ajas. 2013.13200 